\title{
Upaya Meningkatkan Kepatuhan Profesional Pemberi Asuhan Pasien Dalam Dokumentasi Rekam Medis
}

\author{
Zakharias Kurnia Purbobinuko $^{1}$, Ratna Prahesti ${ }^{2}$, Kori Puspita Ningsih ${ }^{3}$ \\ ${ }^{1,2,3}$ Health Faculty, Universitas Jenderal Achmad Yani Yogyakarta
}

\begin{tabular}{l}
\hline \hline Article Info \\
\hline Article history: \\
Received August 04, 2021 \\
Revised August 19, 2021 \\
Accepted August 25, 2021 \\
\end{tabular}

\section{Keywords:}

Obedience

Professional

Caregiver Documentation

Medical Records

\begin{abstract}
The existence of hospital demands to ensure the completeness of medical records needs to be supported by the hospital's efforts through a regulation and education to PPAs in the process of documenting medical records. Furthermore, the paradigm of human factors, in this case is PPA in maintaining patient safety, is related to efforts to maintain the quality of medical records. This study aims to explore the hospital's efforts to improve PPA compliance with medical record documentation. This research is a descriptive research with a qualitative approach. Panembahan Senopati Hospital, Bantul, was chosen as the location for the research to be carried out in 2021. The research subjects were doctors, medical records officers, and the head of the medical record installation. The object of this research is internal regulations, reports and documents related to medical record documentation. The results showed that Panembahan Senopati Hospital, Bantul, had tried to improve PPA compliance by establishing regulations in the form of Guidelines for Medical Record Services and SOPs for Filling Medical Records. Efforts from the material aspect were carried out by providing a medical record form made of A4 size paper weighing 80 grams in a rectangular shape with several colors according to user needs and given a medical record form number. Panembahan Senopati Hospital Bantul has conducted a performance assessment every year at the end of the year, but the performance appraisal related to PPA compliance in the medical record documentation has not been stated in the SKP. In an effort to improve PPA compliance in medical record documentation, the KMKP Team sets the number of incomplete initial medical assessments within 24 hours for inpatients through the ER as a priority quality indicator. It is better if Panembahan Senopati Hospital Bantul can apply rewards and punishments, thereby increasing motivation, work culture of documenting medical records and achieving employee job satisfaction.
\end{abstract}

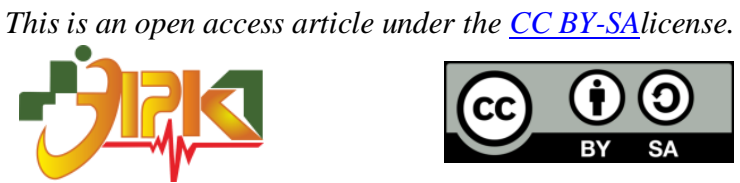

\section{Corresponding Author:}

Zakharias Kurnia Purbobinuko,

Health Faculty,

Universitas Jenderal Achmad Yani Yogyakarta,

Jl. Brawijaya, Ringeroad Barat, Ambarketawang, Gamping, Sleman-Daerah Istimewa Yogyakarta.

Email: zakhariaspurbobinuko@gmail.com 


\section{PENDAHULUAN}

Rekam medis merupakan dokumen yang mendokumentasikan identitas pasien, pemeriksaan, pengobatan, tindakan dan pelayanan lain yang telah diberikan kepada pasien [1]. Rekam medis tersebut memuat keterangan, baik secara tertulis ataupun yang terekam terkait identitas pasien, hasil anamnesis, pemeriksaan fisik, hasil pemeriksaan laboratorium, diagnosis serta seluruh tindakan medis dan pelayanan dan lain yang dilakukan oleh Profesional Pemberi Asuhan (PPA) kepada pasien. Oleh karena itu nilai medis terkandung dalam rekam medis, karena PPA dalam memberikan pelayanan, pengobatan maupun tindakan mengacu pada informasi yang terdapat pada rekam medis.

Penyelenggarakan pelayanan rekam medis untuk pasien merupakan kewajiban bagi rumah sakit [2]. Kelengkapan rekam medis menjadi salah satu indikator yang dapat digunakan untuk mengukur mutu pelayanan kesehatan di Indonesia. Pemerintah Indonesia menetapkan indikator kelengkapan rekam medis $1 \times 24$ jam pada standar pelayanan minimal rekam medis di rumah sakit [3]. Satu diantara standar pelayanan minimal rekam medis adalah kelengkapan rekam medis dalam waktu 1x24 jam sebesar 100\% [3]. Salah satu masalah yang dihadapi rumah sakit adalah ketidaklengkapan rekam medis. Hasil penelitian [4] yang berjudul "Analisis Kuantitatif Ketidaklengkapan Pengisian Resume Medis Berdasarkan Program Quality Assurance (Suatu Studi di Rumah Sakit Delta Surya Sidoarjo)" menunjukkan pada bulan Januari-April 2018 rata-rata persentase kelengkapan resume medis sebesar 96\%. Hasil penelitian sebelumnya di RSUD Panembahan Senopati Bantul tahun 2019 menunjukkan bahwa capaian kelengkapan rekam medis 1x24 jam setelah mendapat pelayanan pada semester I mencapai 98,20\%, sedangkan pada semester II sebesar 98,10\% [5]. Dari penelitian tersebut dapat disampaikan bahwa kelengkapan rekam medis belum tercapai $100 \%$. Masalah ketidaklengkapan rekam medis tersebut disebabkan rekam medis mendokumentasikan informasi mengenai riwayat kesehatan dan tindakan pada pasien, guna meningkatkan mutu mutu pelayanan kesehatan melalui tertib administrasi. Informasi yang dihasilkan dari rekam medis akan bernilai akurat jika rekam medis diisi dengan lengkap [6].

Adanya tuntutan rumah sakit untuk menjamin kelengkapan rekam medis, perlu didukung dengan upaya rumah sakit melalui suatu regulasi dan edukasi kepada para PPA dalam proses pendokumentasian rekam medis. Lebih lanjut bahwa paradigma faktor manusia, dalam hal ini adalah PPA cukup berperan dalam menjaga mutu rekam medis, yang tentunya juga akan berpengaruh pada keselamatan pasien [7]. Penelitian ini bertujuan untuk mengeksplorasi upaya rumah sakit dalam meningkatkan kepatuhan PPA pada dokumentasi rekam medis.

\section{METODE PENELITIAN}

Penelitian ini merupakan penelitian deskriptif dengan pendekatan kualitatif. Rancangan penelitian menggunakan metode cross sectional. RSUD Panembahan Senopati Bantul terpilih sebagai lokasi penelitian ini, karena RS Pemerintah tipe B dan telah terkareditasi Paripurna. Subjek penelitian adalah dokter, petugas rekam medis, dan kepala instalasi rekam medis. Objek penelitian ini adalah regulasi internal, laporan dan dokumen yang berkaitan dengan dokumentasi rekam medis di RSUD Panembahan Senopati Bantul. Instrumen penelitian ini menggunakan pedoman wawancara, ceklist observasi dan ceklist studi dokumentasi. Untuk menjamin validitas data, dilakuan triangulasi sumber dan triangulasi teknik, setelah data diperoleh dilakukan analisis data kualitatif. Selanjutnya dilakukan content analysis/analisis isi, dimana data yang diperoleh dari wawancara, studi dokumentasi dan observasi dilakukan analisis. Selanjutnya data dipilih menurut relevansinya, agar dapat disajikan dalam bentuk narasi [8]. Etical clearance dilakukan untuk menjamin bahwa penelitian ini sesuai etika penelitian. 
3. HASIL DAN PEMBAHASAN

1. Upaya Meningkatkan Kepatuhan PPA Dalam Dokumentasi Rekam Medis - Upaya dari aspek Regulasi

Dalam upaya meningkatkan kepatuhan dokumentasi rekam medis oleh PPA, maka RSUD Panembahan Senopati Bantul menyusun beberapa regulasi berupa Pedoman Pelayanan Rekam Medis dan Standar Prosedur Operasional (SPO). Pada pedoman pelayanan rekam medis telah disahkan oleh Direktur RSUD Panembahan Senopati Bantul dengan nomor 87 tahun 2017 tentang Pedoman Pelayanan Rekam Medis di RSUD Panembahan Senopati Bantul, sedangkan untuk SOP telah disahkan oleh Direktur RSUD Panembahan Senopati Bantul dengan nomor 13.0055.312.2.14.02 No.Rev.4 tentang SPO Pengisian Rekam Medis. Adanya pedoman dan SOP tersebut diharapkan digunakan oleh para PPA sebagai acuan dalam dokumentasi rekam medis di RSUD Panembahan Senopati Bantul. Regulasi merupakan suatu dokumen pengaturan berupa kebijakan, peraturan direktur, keputusan direktur, pedoman, panduan, prosedur (SPO) maupun program yang disusun oleh rumah sakit [9]. SPO merupakan suatu perangkat intruksi yang menjelaskan Langkah kegiatan yang harus dilakukan untuk menyelesaikan suatu pekerjaan. SOP bertujuan untuk menjamin proses kerja berjalanaman, konsisten, efektif dan efisien melalui pemenuhan standar yang berlaku guna meningkatkan mutu pelayanan. Pada standar MIRM 13.1 juga disampaikan bahwa rumah sakit perlu memiliki regulasi yang mengatur isi spesifik rekam medis pasien guna menjamin kesinambungan asuhan yang diberikan PPA [9]. Oleh karena itu SPO sangat diperlukan karena akan digunakan sebagai acuan yang dibuat secara tetulis dan dibakukan guna menggambarkan langkah-langkah kegiatan dilaksanakan bagaimana, kapan, dimana dan oleh siapa [10].

Dalam upaya menjamin PPA mengetahui Pedoman dan SPO tersebut, maka RSUD Panembahan Senopati Bantul melakukan sosialisasi Pedoman dan SPO kepada PPA. Hasil penelitian [11] menunjukkan bahwa kelengkapan rekam medis di RS balung termasuk dalam kategori jelek yang disebabkan ketidakpahaman prosedur dan pengetahuan PPA yang rendah SPO dan alur rekam medis. Keberhasilan pelaksanaan SPO juga dipengaruhi oleh latar belakang pendidikan sumber daya manusia heterogen diunit kerja [12]. Hasil penelitian lain juga menunjukkan bahwa faktor yang menentukan keberhasilan impelentasi SPO adalah adanya faktor belum dilakukannya sosialisasi, faktor sumber daya manusia dan faktor latar belakang pendidikan [13].

Selanjutnya Instalasi Rekam Medis RSUD Panembahan Senopati Bantul bertanggung jawab untuk mendokumentasikan bukti sosialiasi. Hal ini disebabkan karena kelengkapan rekam medis 1x24 jam setelah pelayanan merupakan indikator Standar Pelayanan Minimal Rumah Sakit (SPM RS) di Instalasi Rekam Medis RSUD Panembahan Senopati Bantul. Adanya standar kelengkapan rekam medis tersebut juga tertuang pada Peraturan Bupati Bantul Nomor 74 tahun 2017 tentang Pedoman Pelaksanaan Pengelolaan Keuangan Badan Layanan Umum Daerah (BLUD) di Rumah Sakit Umum Daerah (RSUD) Panembahan Senopati Kabupaten Bantul. SPM RS wajib dibuat setiap semester dan tahunan paling lambat dua bulan setelah berakhirya periode laporan [3].

Dalam upaya memenuhi SPM RS dan untuk menunjukkan akuntabilitas kinerja sebagai BLUD maka RSUD Panembahan Senopati perlu menjamin kelengkapan dokumentasi rekam medis. Hal ini diakrenakan data SPM RS digunakan untuk memenuhi persyaratan perundang-undangan, persyaratan akuntabiltas BLUD, dan tolak ukur kinerja rumah sakit, SPM RS juga merupakan hal yang dipersyaratkan oleh pelanggan,dan SPM RS dapat digukan untuk mengukur mutu pelayanan sesuai Standar Nasional Akreditasi Rumah Sakit (SNARS) [11]. 


\section{- Upaya dari Aspek Budaya Kerja}

Dalam upaya meningkatkan motivasi kerja karyawan, maka Pimpinan RSUD Panembahan Senopati melakukan evaluasi penilaian kinerja untuk setiap tenaga kerja yang dilakukan setiap tahun sekali di akhir tahun. Penilaian kinerja untuk tenaga kerja Pegawai Negeri Sipil (PNS) berupa penilaian Sasaran Kinerja Pegawai (SKP), akan tetapi indikator spesifik kepatuhan PPA dalam mengisi rekam medis tidak tertuang di dalam penilaian SKP. Begitu juga dengan peningkatan motivasi kerja melalui adanya reward dan punishment pada kepatuhan PPA mengisi rekam medis juga belum ada. Saat ini Instalasi Rekam Medis RSUD Panembahan Senopati Bantul menyusun laporankelengkapan rekam medis setiap triwulan untuk diserahkan kepada wakil direktur pelayanan dan penunjang, kepala Bidang Pelayanan Medis, kepala Bidang Keperawatan dan Mutu, serta Ketua Komite Keperawatan. Sehingga diketahui Dokter, bangsal dan jenis formulir yang tidak lengkap.

Adanya kondisi tersebut menunjukkan bahwa budaya kerja PPA khususnya dalam dokumentasi rekam medis telah berjalan sesuai dengan regulasi yang telah disosialisasikan di rumah sakit. Dokter mendokumentasikan rekam medis sesuai dengan kewajiban dokter. Pada pendokumentasian rekam medis, dokter yang merawat pasien dapat medelegasikan pendokumentasian rekam medis pada tenaga kesehatan lainnya selain dokter ataupun dokter gigi [2].

Dalam upaya meningkatkan motivasi dan budaya kerja tersebut sebaiknya RSUD Panembahan Senopati Bantul juga menerapkan reward dan punishment, sehingga tercapai kepuasan kerja karyawan. Dengan adanya pemberian reward sebagai bentuk pemberian penghargaan atas kepatuhan PPA dalam mengisi rekam medis, dan punishment sebagai bentuk teguran apabila PPA tidak patuh mengisirekam medis. Hasil penelitian sebelumnya menunjukkan bahwa dalam mengevaluasi kelengkapan pengisian rekam medis pelu diberikan peringatan berupa teguran kepada dokter yang belum melengkapi rekam medis [14]. Belum adanya sistem reward dan punishment juga menjadi salah satu faktor penyebab ketidaklengkapan rekam medis [15]. Penelitian lain juga menunjukkan bahwa terdapat hubungan antara kepuasan kerja dengan kinerja karyawan. Dimana, semakin tinggi kepuasan kerja maka motivasi karyawan untuk bekerja lebih keras semakin meningkatkan dan akan berdampak pada semakin meningkatnya kinerja karyawan [16].

\section{- Upaya dari Aspek Material}

Dalam upaya meningkatkan kepatuhan PPA dalam mendokumentasikan rekam medis, maka RSUD Panembahan Senopati Bantul mendesain formulir rekam medis sesuai dengan kebutuhan pengguna. Formulir rekam medis di RSUD Panembahan Senopati Bantul menggunakan kertas ukuran A4 berat 80 gram berbentuk persegi panjang dengan beberapa warna sesuai kebutuhan pengguna, seperti formulir gawatdarurat berwarna merah dan formulir ringkasan masuk keluar berwarna hijau. Bahan material tersebut seperti hasil penelitian sebelumnya di lab RMIK Unjaya [17] dan Puskesmas Kauman Ponorogo [18] yang menggunakan kertas ukuran A4 berat 80 gram berbentuk persegi panjang pada desain aspek anatomi formulir rekam medis. Bahan formulir tersebut cukup baik, karena cukup tebal, tidak mudah rusak dan sobek.

Di RSUD Panembahan Senopati Bantul juga sudah dilengkapi dengan nomor formulir rekam medis, sesuai aturan kontrol dokumen di RSUD Panembahan Senopati Bantul. Seperti contohnya formulir ringkasan masuk keluar menggunakan nomor RM.RI.01.01 yang berarti rekam medis rawat inap halaman depan atau pertama yang telah direvisi satu kali. Dan adanya penggunaan warna dan penomoran formulir rekam medis di RSUD Panembahan Senopati Bantul tersebut bertujuan untuk mempermudah pengguna maupun PPA dalam mengidentifikasi dan menemukan formulir rekam medis. Salah satu solusi untuk memudahkan dokter dalam mengisi rekam medis adalah dengana adanya kejelasan formulir rekam 
medis dan efisiensi format formulir rekam medis [16]. Akan tetapi hasil penelitian di RSD Balung menunjukkan ketersediaan format rekam medis, kejelasan format rekam medis, kemudahan cara pengisian format rekam medis, kesesuaian lembar formulir rekam medis, tidak berpengaruh pada pengisian rekam medis [12].

\section{Peran Tim Peningkatan Mutu dan Keselamatan Pasien (PMKP) Guna Meningkatkan Kepatuhan PPA Dalam Dokumentasi Rekam Medis}

Komite Mutu dan Keselamatan Pasien (KMKP) di RSUD Bantul bertanggung jawab langsung kepada Direktur. Tim KMKP bertugas untuk melakukan identifikasi perbaikan atau mengurangi dan mencegah kejadian tidak diharapkan berdasarkan evidence-based. Pelaporan data dari tim KMKP disampaikan secara rutin berdasarkan hasil assessment secara intensif, sehingga dapat diguankan sebagai dasar pertimbangan dalam menyusun upaya perbaikan dan rencana prioritas program perbaikan, karena sebagian besar rumah sakit termasuk Rumah Sakit Umum Daerah Panembahan Senopati Bantul, memiliki sumber daya yang terbatas, sehingga rumah sakit perlu merencanakan dengan baik fokus penempatan sumber dayanya untuk proses perbaikan yang konsisten dan kontinue. Menurut SNARS edisi 1 pada Standar PMKP 1 bahwa rumah sakit memiliki Komite/Tim atau bentuk organisasi sejenis lain yang berkompeten dalam mengelola kegiatan peningkatan mutu dan keselamatan pasien [10].

Dalam upaya meningkatkan kepatuhan PPA dalam dokumentasi rekam medis, maka Tim KMKP menetapkan angka ketidaklengkapan assesmen awal medis dalam 24 jam pada pasien rawat inap melalui Instalasi Gawat Darurat (IGD) sebagai indikator mutu prioritas di RSUD Panembahan Senopati Bantul. Upaya yang dilakukan RSUD Paembahan Senopati Bantul tersebut sejalan dengan Standar PAP 2.1 bahwa guna mengetahui dan menetapkan prioritas tindakan, prosedur, dan asuhan PPA lainnya untuk memenuhi kebutuhan pasien asesmen awal dan asesmen ulang perlu disusun proses perencanaan yang bersifat kolaboratif yang dilakukan oleh dokter dan PPA lainnya seperti perawat, ahli gizi, apoteker, dan sebagainya. Dalam waktu 24 jam terhitung saat diterima sebagai pasien rawat inap maka rencana asuhan harus diselesaikan [10].

Berikut hasil angka ketidaklengkapan assesmen awal medis dalam 24 jam pada pasien rawa tinap melalui IGD di RSUD Panembahan Senopati Bantul tahun 2020:

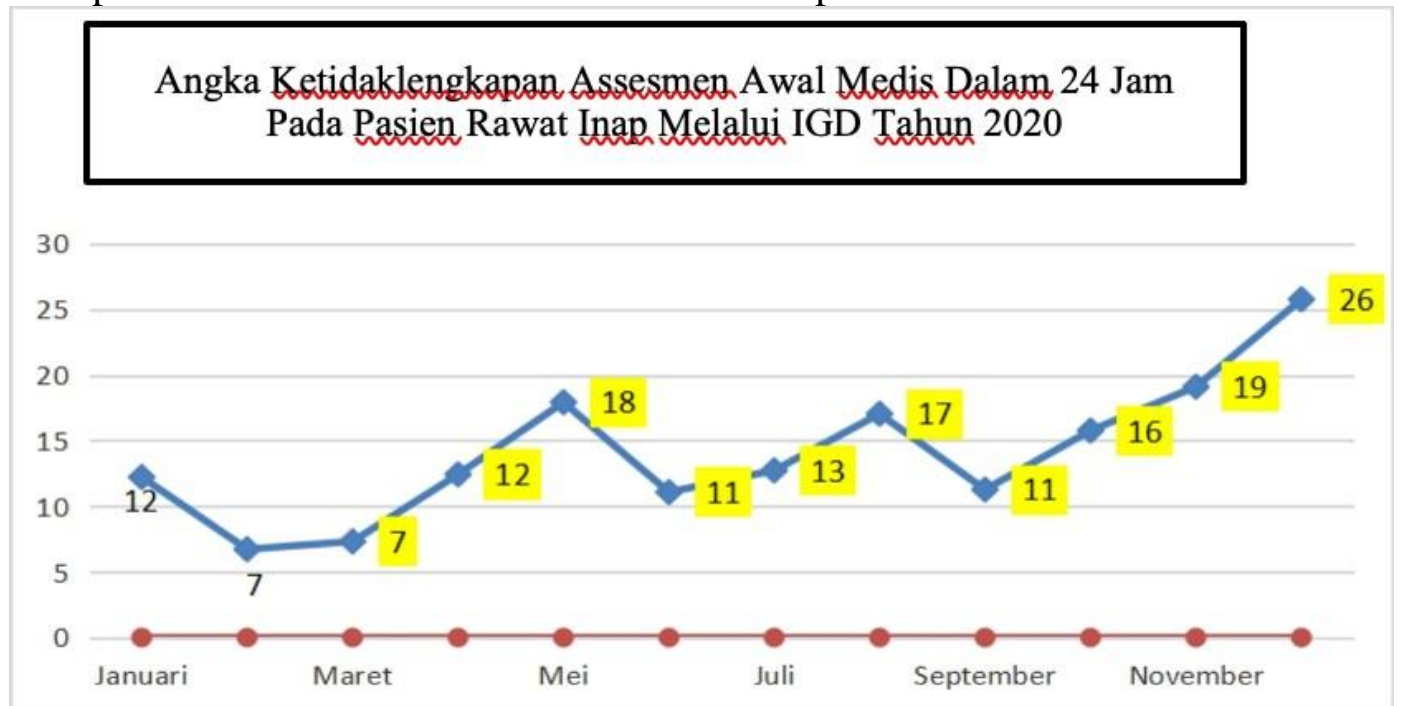

Gambar 1. Angka Ketidaklengkapan Assesmen Awal Medis Dalam 24 Jam Pada Pasien Rawat Inap Melalui IGD

Angka ketidaklengkapan assesmen awal medis dalam 24 jam pada pasien rawat inap di RSUD Panembahan Senopati Bantul pada tahun 2020 mengalami tren kenaikan dari bulan kebulan, meskipun pada bulan Mei dan Bulan Agustus mengalami penurunan. 
Beberapa hal ini disebabkan terdapat dokter yang masuk secara bergantian dan juga pasien masuk pada hari libur atau sabtu sore, sehingga dokter DPJP dalam melengkapi lembar assesmen awal medis terlambat. Hal ini serupa dengan penelitian literatur riview yang menyampaikan faktor lain yang menyebabkan rekam medis tidak lengkap adalah kurangnya kesadaran dokter mengisi lengkap rekam medis. Kesibukan dokter menjadi alasan utama dokter tidak melengkapi resume medis. Akan tetapi seharusnya ditengah kesibukan dokter tetap bisa memenuhi kewajiban dokter dalam membuat rekam medis [16]. Setiap dokter yang menjalankan praktik kedokteran wajib membuat rekam medis dengan segera dan lengkap [2].

Sesuai dengan tugas dari Tim KMKP maka ketika terjadi ketidaktercapaian indikator mutu prioritas rumah sakit, maka perlu dilakukan rencana tindak lanjut. Hal ini sesuai dengan tugas Komite PMKP menurut SNARS yang satu diantaranya adalah membantu dan melakukan koordinasi dengan pimpinan unit pelayanan dalam memilih prioritas perbaikan, pengukuran mutu/indikator mutu, dan menindaklanjuti hasil capaian indikator [10].

Tim KMKP RSUD Panembahan Senopati Bantul dalam upaya perbaikan mutu menggunakan metode Siklus Plan Do Check Action (PDCA). Tindak lanjut tersebut merupakan bentuk fungsi pengawasan dalm proses manajemen. Fungsi pengawasan tersebut berkaitan dengan fungsi perencanaan, pengorganisasian dan pelaksanaan.

Adanya fungsi pengawasan mampu menilai keberhasilan program dengan cara membandingkan target dengan hasil yang dicapai. Apabila terjadi suatu penyimpangan maka menunjukkan Pipimpinan harus segera mengatasi penyimpangan sedini mungkin dengan cara mendeteksi, mencegah, mengurangi maupun mengendalikan [19]. Hal ini sesuai penelitian serupa di RSUD Panembahan Senopati Bantul bahwa upaya yang dilakukan untuk meningkatkan kelengkapan rekam medis dan informed consent adalah dengan memberikan feedback kepada dokter setiap 3 bulan sekali melalui bidang pelayanan medis dan komite medis terkait hasil kelengkapan rekam medis dan komponen yang tidak lengkap per nama dokter. Hal ini dilakukan dengan harapan Komite Medis RSUD Panembahan Senopati Bantul akan memberikan edukasi kepada dokter pentingnya tertib adminstrasi mengisi rekam medis dan informed consent dengan lengkap setelah selesai memberikan pelayanan kepada pasien [6].

\section{KESIMPULAN}

RSUD Panembahan Senopati Bantul telah berupaya meningkatkan kepatuhan PPA dengan menetapkan regulasi berupa Pedoman Pelayanan Rekam Medis dan SPO Pengisian Rekam Medis. Upaya yang dilakukan RSUD Panembahan Senopati Bantul dari aspek material dilakukan dengan menyediakan formulir rekam medis berbahan kertas ukuran A4 berat 80 gram berbentuk persegi panjang dengan beberapa warna sesuai kebutuhan pengguna dan diberikan nomor formulir rekam medis. RSUD Panembahan Senopati Bantul telah melakukan penilaian kinerja setiap tahun sekali di akhir tahun, akan tetapi penilai kinerja berkaitan dengan kepatuhan PPA dalam dokumentasi rekam medis belum tertuang dalam SKP. Budaya kerja PPA dalam dokumentasi rekam medis telah berjalan sesuai dengan regulasi yang telah disosalisaikan di rumah sakit. Dalam upaya meningkatkan kepatuhan PPA dalam dokumentasi rekam medis, maka Tim KMKP menetapkan angka ketidaklengkapan assesmen awal medis dalam 24 jam pada pasien rawat inap melalui Instalasi Gawat Darurat (IGD) sebagai indikator mutu prioritas di RSUD Panembahan Senopati Bantul. Sebaiknya dalam upaya meningkatkan motivasi, budaya kerja dan kepatuhan PPA dalam dokumentasi medis, maka RSUD Panembahan Senopati Bantul dapat menerapkan reward dan punishment, sehingga tercapai kepuasan kerja karyawan. 


\section{REFERENCES}

[1] Kemenkes RI, Peraturan Menteri Kesehatan RI Nomor 269/Menkes/Per/III/2008 tentang Rekam Medis. Jakarta: Kemenkes RI, 2008.

[2] Konsil Kedokteran Indonesia, "Manual Rekam Medis - Konsil Kedokteran Indonesia," p. 5, 2006.

[3] Kemenkes RI, Permenkes RI Nomor: 129/Menkes/SK/II/2008 tentang Standar Pelayanan Minimal Rumah Sakit. Jakarta: Kemenkes RI, 2008.

[4] I. Suhartina, "Analisis Kuantitatif Ketidaklengkapan Pengisian Resume Medis Berdasarkan Program Quality Assurance (Suatu Studi di Rumah Sakit Delta Surya Sidoarjo)," J. Kesehat. Vokasional, vol. 4, no. 2, 2019, doi: 10.22146/jkesvo.43948.

[5] K. . Ningsih and S. N. Adhi, "Evaluasi Standar Pelayanan Minimal Rekam Medis di RSUD Panembahan Senopati Bantul," Indones. Heal. Inf. Manag. J, vol. 8, no. 2, 2020.

[6] S. C. Budi, Manajemen Unit Kerja Rekam Medis. Yogyakarta: Quantum Sinergis Media, 2011.

[7] H. Hutama and E. Santosa, "Evaluasi Mutu Rekam Medis Di Rs Pku 1 Muhammadiyah Yogyakarta: Studi Kasus Pada Pasien Sectio Caesaria," J. Med. eticolegal dan Manaj. Rumah Sakit, vol. 5, no. 1, pp. 25-34, 2016, doi: 10.18196/jmmr.5103.

[8] Sugiyono, Metode Penelitian Kuantitatif Kualitatif dan $R \& D$. Bandung: Alfabeta, 2014.

[9] KARS, Standar Nasional Akreditasi Rumah Sakit, 1 st. Jakarta: KARS, 2017.

[10] S. N. Adhi and K. P. Ningsih, "Manajemen Data Standar Pelayanan Minimal Rumah Sakit," J. Rekam Medis dan Inf. Kesehat., vol. 3, no. 2, pp. 53-62, 2020.

[11] G. Wuryandari, "Peningkatan Kelengkapan Rekam Medis," Adm. Kebijak. Kesehat., vol. 11, no. 2, pp. 60-65, 2013.

[12] K. P. Ningsih, U. Tunnisa, and N. Erviana, "Manajemen Resiko Redesign Sistem Penjajaran Rekam Medis dengan Metode Failure Mode and Effect Analysis (FMEA)," Indones. Heal. Manag. J, vol. 8, no. 1, pp. 8-20, 2020.

[13] R. S. Dukma and Siswati, "Tinjauan Pelaksanaan Standar Prosedur Operasional Distribusi Rekam Medis Rawat Jalan Di Rumah Sakit Umum Daerah Kota Bekasi," J. INOHIM, vol. 5, no. 2, pp. 125-129, 2017.

[14] D. Indrawan, "Faktor-Faktor Yang Mempengaruhi Kepatuhan Dokter Dalam Mengisi Rekam Medis Di Unit Rawat Inap Rumah Sakit Wava Husada," J. Islam. Med, vol. 1, no. 2, pp. 55-66, 2017, doi: 10.18860/jim.v1i2.4454.

[15] M. K. Wirajaya and N. Nuraini, "Faktor-Faktor yang Mempengaruhi Ketidaklengkapan Rekam Medis Pasien pada Rumah Sakit di Indonesia," J. Manaj. Inf. Kesehat.I ndones, vol. 7, no. 2, p. 165, 2019, doi: 10.33560/jmiki.v7i2.225.

[16] K. . Ningsih, Hubungan Beban Kerja Dan Kepuasan Kerja Dengan Kinerja Karyawan Di Instalasi Rekam Medis Rumah Sakit Mata 'Dr.YAP' Yogyakarta. Surakarta: Universitas Muhammadiyah Surakarta, 2013.

[17] K. P. Ningsih and Z. S. Mahbubah, "Analisis Desain Formulir General Consent Rawat Inap (Studi Kasus di Lab RMIK Unjaya)," Indones. Heal. Inf. Manag. J, vol. 9, no. 1, pp. 38-46, 2021.

[18] Puspitasari and et all, "Perancangan Desain Formulir Rekam Medis Pasien Rawat Jalan Poliklinik Umum Di Puskesmas Kauman Kabupaten Ponorogo," Glob. Heal. Sci, vol. 2, no. 2, pp. 87-90, 2017, doi: 10.1016/j.cbpa.2012.10.010.

[19] S. Herlambang and A. Murwani, Cara Mudah Mempelajari Manajemen Kesehatan dan Rumah Sakit. Yogyakarta: Gosyen Publishing, 2012. 


\section{BIOGRAPHIES OF AUTHORS}

\begin{tabular}{|l|l|} 
Zakharias Kurnia Purbobinuko. Dosen Program Studi Rekam Medis dan Informasi \\
Kesehatan (D-3) Fakultas Kesehatan, Universitas Jenderal Achmad Yani Yogyakarta.
\end{tabular}

